DOI https://doi.org/10.18551/rjoas.2017-05.26

\title{
THE INFLUENCE OF BUSINESS LOCATION ON COMPETITIVE ENVIRONMENT, COMPETITIVE STRATEGY, AND RURAL BANKS PERFORMANCE ON THE EXAMPLE OF BANK PERKREDITAN RAKYAT
}

\author{
Tjahjono Endro* \\ Faculty of Social and Political Sciences, 17 Agustus 1945 Surabaya University, Indonesia
}

\author{
Alhabsji Taher, Arifin Zainul, Utami Hamidah Nayati \\ Faculty of Administrative Science, University of Brawijaya, Indonesia
}

*E-mail: endro@untag-sby.ac.id

\begin{abstract}
This study aims to examine the influence of business location on competitive environment, competitive strategy, and BPR Performance. The respondents were 153 from 325 conventional BPRs in East Java Province-Indonesia. The data was analyzed using GSCA model. Analysis result shows that location has influence over the competitive environment and competitive strategy, but not for performance. Competitive environment has influence over the competitive strategy, but not for performance, conversely competitive strategy has positive influence over the performance.
\end{abstract}

\section{KEY WORDS}

Business, location, competitive environment, performance.

For service business like bank, having strategic location is critical to find customer. Even though the use of e-banking becomes popular recently, but bank location is always an important factor for customer to choose bank (Robbins, 2006). In urban areas, BPR is located at high-traffic areas, traditional markets, and densely populated areas. While in countryside, BPR is commonly sat in sub district capital or at market and shopping areas as economic hub. The more strategic location had, the bigger the benefit got.

Site selection has implication of competitive environment faced and performance as well. Different location has different competitive environment. Location placed next to market enables bank to provide better service to customer who in the end will increase his/her loyalty (Kumar and Suresh, 2008). A favorable area also gives cost advantages which are hard to imitate by a potential newcomer (Stahl and Grigsby, 1992). There are many companies that precisely choose location next to competitor to attract much more customers (Kumar and Suresh, 2008). Location also influences performance. According to Buffa and Sharin (1999), uniform price creates different cost. If the input cost does not depend on location, different location creates different income. Fahmi (2013) stated that the right place did not only determine income, but also could reduce costs, gave influence on profit and business continuity. Location has not only short-term but also long-term strategic value.

BPR location becomes an important factor to learn now in line with the number of commercial bank and microfinance institution (LKM) getting high which also serves micro and small business segment. Strategic locations that were monopolized by BPR have been developed to become a location filled with various financial institutions offering allied product. In order to overcome this obstacle, BPR can optimize the local potential as effective competitive equipment to improve performance. Competitive strategic arrangement by including location variable makes formula of competitive strategy more comprehensive due to involving several factors that influence their success. This way is expected to get better performance. This idea is also supported by Aaker's (1988) concept stating that location has influence over the competitive strategy. Cost strategy can be reached through several ways such as location. Sanchez and Heene (2004) also stated that cost leadership strategy or differentiation strategy is influenced by location. 
Several studies analyzing relations between location, competitive environment, competitive strategy, and performance have been done a lot, but the one that especially analyzes relations between location and strategy does not find yet. The study conducted by Hannan and Prager (2008) and Geyfman and Scott (2010) concluded that location is correlated with competitive environment. Myers and Kenneth's (2003) study found that location influences bank financial. The study carried out by Kim et al. (2004), Li and Li (2008), and Parnell et al. (2012) concluded that competitive environment influences effectiveness of competitive strategy used. Competitive environment also has influence over the performance. A study by Schafer et al. (2005), Sabihaini (2011), and Shaher et al. (2011) stated that bank performance is influenced by its environment. The study carried out by Eraslan (2008), Li and Li (2008), and Parnell et al. (2012) concluded that type of competitive strategy is correlated with performance.

This study aims to test the influence of location upon competitive environment, competitive strategy, and BPR performance. Problem statements are: (1) Does location have significant influence over the competitive environment, competitive strategy, and performance?; (2) Does competitive environment have significant influence over the competitive strategy and performance?; (3) Does competitive strategy have significant influence over the performance?

\section{LITERATURE REVIEW}

Location is a place where bank operates its activity, including: head office, branch office, sub-branch office, cash office, and until outlet. Decision to choose a particular location is included that bank tends to focus on profit and income, things related to demography (age, income, population/distribution area), competition, traffic light pattern, customer access, and coziness (Stevenson and Chuong, 2014). Location becomes one of the defining factors of the success rate for sale of service. Bank location tends to approach customer, another bank, and closed to trade service. The existence of bank in a strategic location will much help bank's effort to find customer. The importance rate of location for bank depends on the type and level of customer interaction with bank, i.e.: (1) whether customer comes to bank service provider, (2) whether bank service provider visits customer, or (3) business transaction of bank service is performed through the help of electrical equipment. For the first type, location is critical for the success of transaction since customer has to get access easiness, conversely on the second and third type; location is less relevant (Sumarni, 2002). Location has influence over the competitive environment. Different location creates different competitive environment faced by company (Stahl and Grigsby, 1992). In countryside, consumer still depends on the physical network of branch office as the main distribution channel to get banking service. The lows population growth and saving encourages the stagnation of the barriers to entry, the high loyalty level of customer, thus countryside area is also served by a couples of banks with higher market concentration level (Harvey and Myers, 2008). On the contrary, in rural areas, market is less concentrated since the level of competition is high. Rural society that relies on online system through the use of internet banking is predicted will reduce barriers to entry and increase competition (Sjoberg, 2007).

Location can be part of competitive strategy for company. Decision about location is extremely related to the company strategy (Stevenson and Chuong, 2014). A company like bank considers location as part of strategy and finds a location that will help it to improve market. The right business location causes company to have strategic superiority upon its competitors through low operational cost or better differentiation position. Ownership for strategic location encourages competitors to allocate much more fund or force them to leave the location (Aaker, 1998). Low cost strategy demands a location next to market to reduce transportation cost. Market development strategy demands a location closed to a heavy traffic. A strategy emphasizing on customer coziness requires location owned by him where he/she can perform transaction with his/her business (Stevenson and Chuong, 2014). Location also has influence over the performance in term of: competitive superiority, operational cost, the number of customer, profit and income, customer coziness (Stevenson 
and Chuong, 2014), transportation cost and service quality (Kumar and Suresh, 2008). According to Lee (1985) and Pastor (1998) in Weon et al. (2010) different location creates different performance. In countryside, performance growth is correlated with location growth (Amelia and Afriyenny, 2011). In countryside, bank having several branch offices has higher Return on Equity (ROE) than in rural area, but it also has higher fund cost, lower non-interest income, higher cost of Human Resource upon average income, lower and assets quality (Myers and Kenneth, 2003).

Competitive environment is industrial environment where company competes. It has strong influence in determining the existence of potential strategy (Porter, 1998). Intensity of competition in industry depends upon 6 main strengths: potential new comer, suppliers, buyers, replacement products, competitors, and stakeholders like government (Wheelen and Hunger, 2012). New comer brings new capacity and increases competition. A strong supplier can influence competitive intensity in industry. Consumer concentration will also increase bargaining power. Replacement product which has better quality or produced by high profits industry causes price decrease. There is rivalry among costumers due to pressure or opportunity to improve position can influence industry stability. The government strength can also influence industry through arranged regulation. Environment complexity happened due to the change of customer taste, level of competition, behavior change of fund supplier, and technological advancement has significant influence over the specialty and increases diversification (Sabihaini, 2011). Diversification strategy is performed to help the bank to be more able to stand for to face crisis. Competitive environment also influences level of performance of company achievement since personal or collective influences from the whole strength in the industrial environment. Collective though from those 6 strengths determines the potential of level of Return on Investment. The tougher the strength of each model, the more limited the company capability to increase price and get higher profit (Wheelen and Hunger, 2012). Beneficial industrial environment will increase return on investment (Higgins, 1984). The high barriers to entry will limit competition and increase profits; conversely threat of new comer will limit profits in industry (Stahl and Grigsby, 1992). The highs strength of supplier will encourage input price pressuring company's profit in industry. A strong buyer may ask for low price and high service level which decreases company's profit. Replacement product may be limits price which can be fixed by company so limiting profits. Competition between companies can influence profits. Price competition limits price and sales profit, conversely non-price competition may be also decreases profits since the increase of service and advertisement cost (Sanchez and Heene, 2004). Government regulation on the increase of capital creates efficiency (Kamau, 2011). The more the regulation issued by Central Bank, the lower the performance of the bank (Sabihaini, 2011). In relation with the competition at microfinance institution, Schafer et al. (2005) found that competition is negatively correlated with profitability.

Competitive strategy is a strategy in the level of business that focuses on the increase of product competitive position and company service in the industry or particular market segment served (Wheelen and Hunger, 2012). Good strategy should complete 3 criterions: fit to the company culture, completed with resources, and supported by company stakeholders (Faulkner and Bowman, 1997). In order to outperform another company of this industry, a company can use the strategy of low cost and differentiation (Porter, 1980 in Wheelen and Hunger, 2012). Low cost strategy is ability to design, create, and market allied product through an efficient way than competitor. Differentiation is ability to provide a unique and superior value to buyer from an aspect of quality, special features, or after-sales service. Low cost strategy becomes less effective if there is imitation from competitor, technological finding, or consumer preferences shifting. Conversely, differentiation strategy is less effective if there is imitation of competitor, technological change, or an amount of different price (David, 2006). There is a relation between competitive strategy and performance, but kind of strategy that results best performance still being pros and cons. Low cost strategy enables company to get profitability above average of the industry and the improvement of market share (Porter, 1980; Caves and Ghemawat, 1992). Differentiation strategy gets opportunity to result higher profits than low cost strategy since creating better barriers to entry (Caves 
and Ghemawat, 1992). A lot of experiences in business sector show the highest level of profitability found in a business using low cost-differentiation combined strategy (Pearce and Robinson, 2013), conversely a company which "trapped between "has lower profitability and just moderate market segment (Stahl and Grigsby, 1992).

Performance is achievement reached by an organization in a particular period (Becker, 1996), that reflects an achievement of purposes that has been arranged (Gibson et al., 1987) Company performance covers financial performance, business performance, and organizational performance. Financial performance is related to asset, selling receipts, and profitability. Business performance is related to market such as market segment, development, diversification, and product development. Organizational performance is related to the customer satisfaction, product quality, and social responsibility (Venkatraman and Ramanujam, 1986). Profitability performance is most widely used to assess performance because it is a reflection of various aspects of existing performance, and is the simplest but comprehensive way to know the total of performance of the company given the profit is a reflection of the end result of all activities undertaken. Profitability ratio is an assessment of company's capability to gain profits within a certain period expressed as a percentage of assets and capital. Profitability assessment includes ROA (net profit before tax/total assets) and ROE (net profit after tax/own capital) (Sinkey, 1986). ROA reflects the ability of management to generate profits from all assets owned, while ROE describes the ability of management in utilizing their own capital to generate profits for the owner.

\section{CONCEPTUAL FRAMEWORK AND HYPOTHESES}

Company performance is influenced by the competitive environment encountered and strategies employed. Changes in the competitive environment lead to changes in performance. On the other hand, the difference in strategy carried out also leads to differences in performance. In order to obtain the best performance, there needs to be a match between the strategies that is run with the environment at hand. For service companies such as banks, location is strategic factor that can influence performance. Site selection is controlled but the impact it generates may be uncontrollable due to the influence of environmental dynamics. Therefore, location determination can be part of a competitive strategy to improve performance.

This research model is built from several models of previous research findings: $\mathrm{Li}$ and Li (2008), Geyfman and Scott (2010), Shaher et al. (2011), and Parnell et al. (2012) and theoretical studies as described in section two. The research hypotheses are:

$\mathrm{H} 1$ : Location has significant influence over the Competitive Environment;

$\mathrm{H} 2$ : Location has significant effect on Competitive Strategy;

H3 : Location has significant influence over the Performance;

H4: Competitive Environment has significant influence over the Competitive Strategy;

H5: Competitive Environment has significant influence over the Performance;

H6: Competitive Strategy has significant influence over the Performance.

Acceptance/rejection of the hypothesis is based on the critical ratio value (CR) of 1.96 to 1.96 with a significance level of 0.05 . If the value of CR/Sig is $>1.96$ then Ho is rejected and $\mathrm{Ha}$ is accepted. If the value of CR/Sig is $<1.96$ then $\mathrm{Ho}$ is accepted and $\mathrm{Ha}$ is rejected.

\section{METHODS OF RESEARCH}

This research employed quantitative approach and positivist paradigm (Creswell, 2009; Martono, 2010). This study was undertaken in East Java Province, the region with the largest number of BPRs in Indonesia so reflecting the high level of competition in this industry. Total population $=325$ Conventional BPR. The number of sample is 177 banks; it was fixed based on the Slovin formula (Umar, 2010). The sampling technique used was proportional random sampling area. Sample criteria are BPR that has been operating for at least 3 years and is registered as members of the Association of Rural Banks (Perbarindo). Research respondents included: Commissioners, Directors, Managers, and Branch Heads. The data 
was collected through spreading questionnaire sent by post. Measurement of variables used a Likert scale of 5 gradations ( $1=$ very low, $5=$ very high), except for performance variables using numerical scales in percent units. Exogenous variable was location (X), while endogenous included: competitive environment (Y1), competitive strategy (Y2), and performance (Y3).

Definition of concept and operationalization of research variables are as follows:

1. Location $(X)$ is the place where the bank office is established, either the head office, the branch office, the sub-branch office, or the cash office. Location measurement is reflective by using 5 indicators of Kumar and Suresh (2008) namely, accessibility by private vehicle $(X 1)$, availability of transportation facility $(X 2)$, distance between location and customer (X3), distance from economic hub such as; markets, and commercial areas (X4), and distance to competitors (X5).

2. Competitive Environment (Y1) is an external environment encountered by banks that is reflected in the extent of threat levels per stakeholders. The measurement of competitive environment is reflective by using 6 Porter and Freeman (2007:33) indicators: threats of newcomer (Y11), bargaining power of supplier (Y12), customer bargaining power (Y13), threats of Microfinance Institution (Y14) Other BPRs' threats (Y15), and government pressure (Y16).

3. Competitive Strategy (Y2) is a strategy used by banks to generate competitive advantage on the broad market served. Measurement of competitive strategy is reflective by using 8 Porter (1980) indicators: operational cost efficiency level compared to competitors (Y21), internal operating system efficiency level to reduce costs (Y22), economic scale level to achieve cost advantage (Y23), cost leadership position in industry (Y24), product excellence level (Y25), level of product uniqueness compared to competitors (Y26), level of effort in building a reputation that is difficult to imitate by competitors (Y27), and effectiveness level of advertisement / promotion (Y28).

4. Performance (Y3) is the financial performance of the average profitability achieved by banks over the last 3 years (2012-2014). Performance measurements are reflective by using two indicators. Return on Assets/ROA (Y31) and Return on Equity/ROE (Y32).

5. Of the 177 questionnaires sent, 153 were received back and all were completely filled so they could be analyzed. Participation rate of respondents was $86.44 \%$. The data was analyzed using descriptive statistical analysis method (mean score) and inferential statistical analysis of GSCA model (test of measurement model, structural model test, and overall model test). Measurement model test aims to test the validity and reliability of the research instrument. It was performed by evaluating the convergent validity (factor loading value $>0.50$ ), discriminant validity (AVE value $>0.50$ ), and reliability (Cronbach's alpha value> 0.50). The structural model test aims to determine the relations significance among variables, by comparing the value of $t$-statistics with t-tables (significant if $t$ statistics> t-tables). The overall model test aims to measure the percentage of the model's ability to explain data variations, by evaluating the value of FIT and Adjusted FIT (FIT value $=0-1$, the greater the better).

\section{RESULTS AND DISCUSSION}

Based on Appendix 1, the average score of the Location variable $(X)=3.568$ means that the average location of the BPR office is at the strategic location, characterized by: the availability of adequate public transport facilities, close to competitors or other BPR offices, close to domicile customers, easy to reach by private vehicle, and close to economic hub.

Average score of Competitive Environment $(\mathrm{Y} 1)$ is 3.591 meaning that the average level of competitive environment threats faced by BPR is high, reflected by the high bargaining power of commercial banks as the supplier of funds, the high regulatory pressure from the government, the high level of threats of commercial banks New entrants, high threats of other BPRs as competitors, high threats from Microfinance Institutions as competitors, and high bargaining power of customers as consumers. 
Average score of the Competitive Strategy (Y2) is 3.478, meaning that the average competitive strategy used by BPR is a combined low cost-differentiation strategy: the high level of the efficiency of the internal operating system to reduce costs, the high level of operational cost efficiency compared to competitors, high rates of economic scale to achieve cost advantage, high levels of product excellence in the eyes of customers, high cost leadership positions in industry, high uniqueness of products over competitors, high levels of effort to build a reputation that is difficult to imitate by competitors, and the level of effectiveness of advertising/promotion which is being.

Average score of performance $(\mathrm{Y} 3)$ is 14.943 , meaning that the average performance of BPR is at moderate level, which is characterized by low ROA level and moderate ROE level.

Based on Appendix 2, all load factor values are $>0.50$ and AVE value $>0.50$, so it can be concluded that the validity of all indicators against the variable is good. The results of calculations on reliability also shows that all values of Cronbach Reliability or CR $>0.70$ so it can be concluded that all indicators have good reliability.

Based on Appendix 2, dominant indicator in establishing location variable $(X)$ is $X 4$ (distance of BPR office with economic hub like market or trade area), with loading factor value by 0.780 , the dominant indicator in forming competitive environment variable (Y1) is Y13 (bargaining power of customers as BPR consumers), with the loading factor value by 0.765 , the dominant indicator in forming competitive strategy variables (Y2) is Y24 (position of BPR cost leadership rural banks industry), with loading factor value of 0.786 , and the dominant indicator in shaping the performance variable (Y3) is Y32 ( ROE profitability level of BPR average during the last 3 years), with loading factor value by 0.955 .

According to Appendix 3, the influence of Location (X) on the Competition Environment (Y1) generates path coefficient value by 0.976 and the critical value for CR is 282.82 * significant at $95 \%$ confidence level (CR / Sig > 1.96). Meaning that location has positive and significant influence over the competitive environment. The more strategic the location of the BPR office, the higher the threats of the competitive environment. So Hypothesis 1 "Location has significant influence over the Competitive Environment" is accepted. This research findings support the concept of Kumar and Suresh (2008) and Stevenson and Chuong (2014), and research findings by Sjoberg (2007), Harvey and Myers (2008), Hannan and Prager (2008), Geyfman and Scott (2010) as well.

The influence of location over the competitive strategy generates path coefficient value by 0.628 and critical value for CR by $7.52^{*}$ is significant at confidence level of $95 \%$ (CR/Sig > 1.96). Meaning that Location has significant and positive influence over the Competitive Strategy. The more strategic the location of the BPR office, the more effective the use of combined competitive strategy. So Hypothesis 2 "Location has significant influence over the Competitive Strategy" is accepted. This research finding proves an empirical evidence on the concept of Aaker (1988); Stahl and Grigsby (1992); Sanchez and Heene (2004); and Stevenson and Chuong (2014).

The Influence of Location on Performance generates coefficient path value by 0.148 and the critical value for CR by 1.39 is not significant at the confidence level of $95 \%$ (CR / Sig <1.96). Meaning that location has not significant influence over the performance. So hypothesis 3 "Location has significant influence over the performance" is rejected. This research findings is different with a concept of Buffa and Sharin (1999); Kumar and Suresh (2008); Fahmi (2013), Stevenson and Chuong (2014) and previous research findings of Myers and Kenneth (2003); Geyfman and Scott (2010); and Amelia and Afriyenny (2011). This distinction concludes a big role of competitive strategy employed in achieving performance in rural bank industry.

The Influence of Competitive Environment over the Competitive Strategy generates path coefficient value by 0.357 and critical values for CR by $4.26^{*}$ is significant at confidence level by $95 \%(C R / S i g ~>~ 1.86)$. It means that Competitive Environment has Positive and Significant Influence over the Competitive Strategy. The higher threats of competitive environment, the more effective the combined competitive strategy. So hypothesis 4 "Competitive environment has significant influence over the Competitive Strategy" is 
accepted. This research findings reinforces a concept by Sanchez and Heene (2004); David (2006); Porter (1998); Whelen and Hunger (2012), and previous research findings of Kim et al. (2004); Li and Li (2008); Sabihaini (2011); and Parner et al. (2012).

The Influence of Competitive Environment over the Performance generates path coefficient value by 0.167 and critical value for $C R$ is 1.79 not significant to confidence level by $95 \%(\mathrm{CR} / \mathrm{SIg}<1.96)$. It means that Competitive Environment has not significant influence over the performance. The, hypothesis 5 "Competitive Environment has significant influence over the performance" is rejected. This is different with a concept by Higgins (1984); Stahl and Grigsby (1992); Sanchez and Heene (2004); Wheelen and Hunger (2012), and the research findings of Schafer et al. (2005); Sabihaini (2011); Shaher et al. (2011); and Kamau (2011). This concludes that same as location, competitive environment also has not direct influence over the performance, but through variable of competitive strategy. This finding reinforces a conclusion on the big role of competitive strategy at rural banks industry to achieve performance.

The Influence of Competitive Strategy over the performance generates path coefficient value by 0,664 and critical value for $\mathrm{Cr}$ is $9.29^{*}$ significant at confidence level by $95 \%$ $(\mathrm{CR} / \mathrm{Sig}>1.96)$. Meaning that competitive strategy has positive and significant influence over the performance. The higher the use of combined competitive strategy, the higher the performance of BPR. Then hyphotesis 6 "Competitive strategy has significant influence over the performance" is accepted. This finding reinforces a concept of Porter (1980); Caves and Ghemawat (1992); Stahl and Grigsby (1992); Pearce and Robinson (2013), and research conducted by Eraslan (2008); Li and Li (2008); and Parner et al. (2012).

Based on the appendic 4, FIT value of 0.590 shows that exogenous variable can be explained by model amounting to $59 \%$ and the rest of $41 \%$ can be explained by another variable out of this research model. Considering FIT values $>50 \%$ then it can be concluded that the model is good to explain the phenomenon studied.

BPR industry is a complex business entity which can be studied from various perspectives. This study has several limitations that enable to perform an advanced study:

1. Indicator of location measurement is only limited to the factor of accessibility and distance. The use of different or more different indicators will likely result in different findings. For example: population density, location (rural, urban, and urban), customer characteristics and behavior, and so on.

2. The research model is only able to explain $59 \%$ of the variables that influence performance. There are still $41 \%$ of other variables that influence the performance of BPR. For example: a large asset and capital, quality of human resources, leadership, organizational structure, or corporate culture.

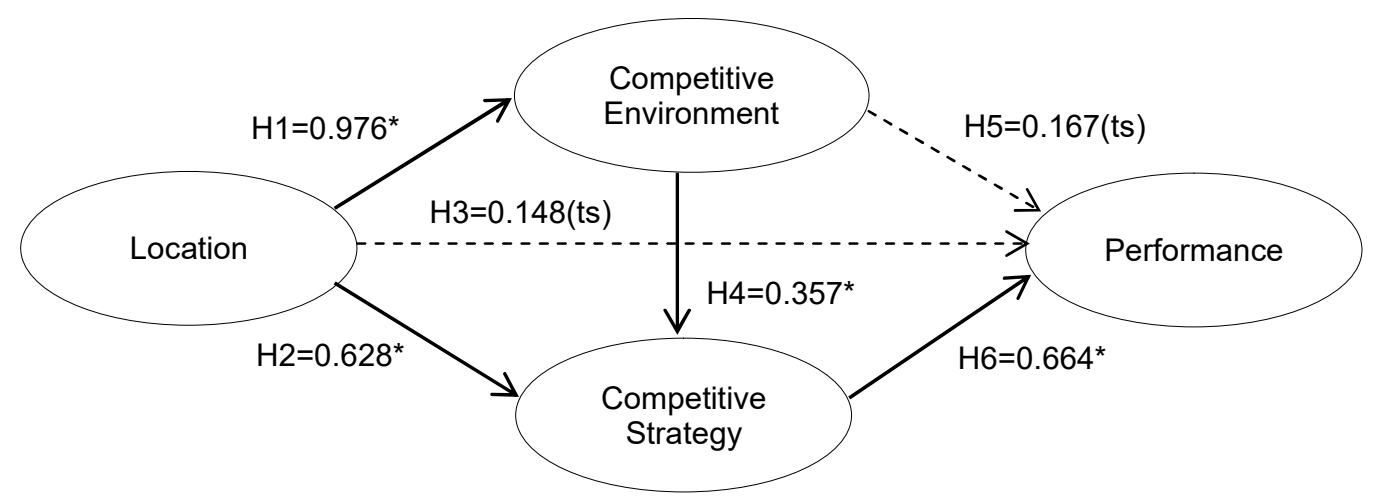

Figure 1 - Research Findings Model

\section{CONCLUSION AND SUGGESTIONS}

According to the problem statements, analysis result, and hypothesis test explained above, then the conclusions are as follows: 
Location has positive and significant influence over the competitive environment and competitive strategy, but has not significant influence over the performance;

Competitive environment has positive and significant influence over the competitive strategy, but not significant over the performance;

Competitive strategy has positive and significant influence over the performance;

Threat of competitive environment is influenced by location;

Effectiveness of low cost-differentiation strategy combination is much more influenced by location compared to threats of competitive environment;

Competitive strategy plays role as perfect mediator in locations-performance and competitive environment-performance relations. Meaning that both location and competitive environment does not influence performance directly. Location and competitive environment will influence the effectiveness of competitive strategy usage that in the end will influence performance.

Based on the conclusion above, recommendations are pointed to the management, government, and further researchers are as follow:

For BPR management: bringing location closer to the economic hub, improving popularity and reputation through promotion, improving association cooperation to encounter competition, and strengthening the role of research and development division to produce innovative ideas;

For government and Financial Services Authority: Determination of clear market segment to avoid direct competition with another commercial bank which is stronger, improving supervision and control on the impact of globalization and IT use to banking industry, and strengthening Perbarindo institutional for member advancement and community welfare;

For further researchers: developing indicators (location: countryside, urban, rural area; competitive strategy: expansion, consolidation, depreciation; performance: CAMEL, BOPO), developing location or research object (commercial bank, regional development bank, Islamic bank, hotel, hospital, trade sector), or developing variables (management characteristics, customer behavior, economic condition, etc.).

\section{REFERENCES}

1. Aaker, D.A. (1988). Developing Business Strategy. $2^{\text {nd }}$ Edition. Wiley and Sons, USA.

2. Amelia, M.R. and Afriyenny, L. (2011). Growth and Performance of Rural Banks. International Credit Union Conference on Social Microfinance and Community Development. BKCU Kalimantan - Gunadarma University.

3. Becker, B. and Gerhart, B. (1996). The Impact of Human Resources Management. Of Organization Performance: Progres and Prospects. Academy of Management Journal, 30(4): $779-801$.

4. Buffa, E.S. and Sarin, R.K. (1999). Manajemen Produksi/Operasi. Agus Maulana (Ed.). $8^{\text {th }}$ Edition. Binarupa Aksara. Jakarta.

5. Caves, R.E. and Ghemawat, P. (1992). Identifying Mobility Barriers. Strategic Management Journal: 1-12.

6. Creswell, J.W. (2009). Research Design: Qualitative, Quantitative, and Mixed Methods Approaches. $3^{\text {th }}$ Edition. SAGE Publications, Inc. California.

7. David, F. R. (2006). Manajemen Strategis: Konsep. Ichsan Setiyo Budi (Ed.). $10^{\text {th }}$ Edition. Salemba Empat. Jakarta.

8. Eraslan, I.H. (2008). The Effects of Competitive Strategies on Firm Performance: A Study in Turkish Textile and Apparel Industry Considering the Mediating Role of Value Chain Activities. Bogazici University. Doctor Tezi. Istambul. Turkey.

9. Fahmi, I. (2013). Manajemen Strategis: Teori dan Aplikasi. Alfabeta. Bandung.

10. Faulkner, D. (1997). The Essence of Competitive Strategy. Endang Sih Prapti (Ed.). Andi.

11. Geyfman, V. and Scott, J. (2010). Challenges and Opportunities for Community Banks in Rural Pennsylvania. The Center for Rural Pennsylvania. 
12. Gibson, J.L., et al. (1987) Organisasi Dan Manajemen: Perilaku, Struktur, Proses. Binarupa Aksara. Jakarta.

13. Hannan, T.H. and Prager, R.A. (2006). The Profitability of Small, Single Market Banks in an Era of Multimarket Banking. Finance and Economics Discussion Series, July $18^{\text {th }}$ 2006. Federal Reserve Board. Washington DC.

14. Harvey, J. and Myers, F. (2008). The Changing Influence of Market Structure on Performance in Rurual Banking Markets 1985 Through 2005. Financial Industry Perspectives. Federal Reserve Bank on Kansas City.

15. Higgins, J.M. (1984). Organizational Policy and Strategic Management: Text and Case. $2^{\text {th }}$ Edition. Dryden Press.

16. Kamau, A.W. (2011). Intermediation Efficiency and Productivity of The Banking Sector in Kenya. Interdiciplinery Journal of Research in Business, 1(9): 12-26.

17. Kim, E., Nam, D. and Stimpert., J.L. (2004). The Applicability of Porter's Generic Strategies in the Digital Age: Assumptions, Conjectures, and Suggestions. Journal of Management, 30(5): 569-89.

18. Kumar, S.A. (2008). Production and Operations Management (with Skill Development, Caselets and Cases). New Age International (P) Limited, Publishers. New Delhi.

19. Li, C.B. and Li, J.J. (2008). Achieving Superior Financial Performance in China: Defferentiation, Cost Leadership, or Both?. Journal of International Marketing, 16: 1-35

20. Martono, N. (2010). Metode Penelitian Kuantitatif: Analisis Isi dan Analisis Data Sekunder. PT Raja Grafindo Persada. Jakarta.

21. Myers, F. and Kenneth, S. (2003). Community Bank Performance in Slower Growing Markets: Finding Sound Strategies for Success". Financial Industry Perspectives 2003. Federal Reserve Bank of Kansas City: 15-30.

22. Parnell, J.A. (2012). How Environmental Uncertainty Affects The Link Between Business Strategy and Performance in SMEs: Evidence From China, Turkey, and The United States. Emerald Group Publishing Limited.

23. Pearce II, J.A. (2013). Strategic Management: Formulation, Implementation, and Control. McGraw-Hill Education. Nia Pramita Sari (Ed.). Manajemen Strategis: Formulasi, Implementasi, dan Pengendalian. Edisi 12. Buku 1. Penerbit Salemba Empat. Jakarta.

24. Porter, M.E. (1980). Competitive Strategy. Free Press. New York.

25. Porter, M.E. (1998). Competitive Strategy. Sigit Suryanto (Ed.) 2007. Strategi Bersaing: Teknik Menganalisis Industri dan Pesaing. Kharisma Publishing Group. Tangerang.

26. Robbins, E. (2006). Location, Location, Location: Has Electronic Banking Affected the Importance of Banking Location?. Federal Reserve Bank of Kansas City, Financial Industry Perspective. September 2006.

27. Sabihaini. (2011). Environmental and Strategy Changing and The Implications on Performance in The Banking Sector. International Journal of Business and Management Tomorrow, 1(2): 1-31.

28. Sanchez, R. and Heene, A. (2004). The New Strategic Management: Organization, Competition, and Competence. John Wiley And Sons, Inc. USA.

29. Schafer, S.M., Smith, H.J. and Linder, J.C. (2005). The power of business models. Business Horizons, 48(3): 199-207.

30. Shaher, T.A. (2011). The Major Factors that Affect Banks Performance in Middle Eastern Countries. Journal of Money, Investment and Banking- Issue, 20: 101-109.

31. Sinkey, Jr., J.F. (1986). Commercial Bank Financial Management in The Financial Services Industry. Mcmillan Publishing Company. New York.

32. Sjoberg, P. (2007). Competition in Swedish Local Banking Markets. Department of Economics and Statistics Goteborg University.

33. Stahl, M.J. and Grigsby, D.W. (1992). Strategic Management for Decision Making. PWSKENT Publishing Company. USA.

34. Stevenson, W.J. and Chuong, S.C. (2014). Operation Management; An Asian Perspective. 9th Edition. McGraw-Hill Education.

35. Angelica et al. (Ed.) 2014. Manajemen Operasi: Perspektif Asia. $9^{\text {th }}$ Edition. Salemba Empat. Jakarta.

36. Sumarni, M. (2002). Manajemen Pemasaran Bank. Liberty. Yogyakarta. 
37. Umar, H. (2010). Desain Penelitian Manajemen Strategik. PT. Raja Persada. Jakarta.

38. Venkatraman (1986). Measurement of Business Performance in Strategy Research: a Comparison of Approaches. Academy of Management Review, 11: 801-814.

39. Weon, H.J., Eui, H.W. and Sik, K.Y. (2010). The Study of Location Strategy for Bank Through The Analysis of Inter-regional Financial Transaction Network. International Journal of u- and e- Service, Science and Technology, 3(1): 21-30.

40. Wheelen, T.L. and Hunger, J.D. (2012). Strategic Management and Business Policy: Achieving Sustainability. $13^{\text {th }}$ Edition. Prentice Hall.

\section{APPENDIXES}

Appendix 1 - Average Score of Variable

\begin{tabular}{|l|l|}
\hline \multicolumn{2}{|c|}{ Means Scores of Latent Variables } \\
\hline Location $(\mathrm{X})$ & 3.568 \\
\hline Competitive Environment(Y1) & 3.591 \\
\hline Competitive Strategy (Y2) & 3.478 \\
\hline Performance (Y3) & 14.943 \\
\hline
\end{tabular}

Appendix 2 - Measurement Model

\begin{tabular}{|c|c|c|c|c|c|c|c|c|c|}
\hline \multirow{2}{*}{ Variable } & \multicolumn{3}{|c|}{ Loading } & \multicolumn{3}{|c|}{ Weight } & \multicolumn{3}{|c|}{ SMC } \\
\hline & Estimate & SE & $\mathrm{CR}$ & Estimate & SE & $\mathrm{CR}$ & Estimate & SE & $\mathrm{CR}$ \\
\hline Location $(\mathrm{X})$ & \multicolumn{9}{|c|}{ AVE $=0.555$, Alpha $=0.799$} \\
\hline $\mathrm{X} 1$ & 0.749 & 0.036 & $20.72^{*}$ & 0.278 & 0.014 & $20.08^{*}$ & 0.562 & 0.053 & $10.55^{*}$ \\
\hline $\mathrm{X} 2$ & 0.770 & 0.032 & $23.78^{*}$ & 0.277 & 0.015 & $18.04^{*}$ & 0.593 & 0.050 & $11.96^{*}$ \\
\hline $\mathrm{X} 3$ & 0.705 & 0.041 & $17.06^{*}$ & 0.251 & 0.013 & 19.51 & 0.497 & 0.058 & $8.61^{*}$ \\
\hline $\mathrm{X} 4$ & 0.780 & 0.035 & 22.42 & 0.269 & 0.014 & 19.67 & 0.609 & 0.054 & 11.33 \\
\hline X5 & 0.717 & 0.036 & $20.02^{*}$ & 0.267 & 0.014 & $19.53^{*}$ & 0.514 & 0.052 & $9.97^{*}$ \\
\hline Competitive Environment (Y1) & \multicolumn{9}{|c|}{ AVE $=0.526$, Alpha $=0.819$} \\
\hline $\mathrm{Y} 11$ & 0.731 & 0.037 & $19.68^{\circ}$ & 0.216 & 0.011 & $18.8^{\circ}$ & 0.535 & 0.053 & $10.0^{*}$ \\
\hline $\mathrm{Y} 12$ & 0.676 & 0.046 & $14.54^{*}$ & 0.215 & 0.015 & 14.68 & 0.457 & 0.062 & $7.34^{*}$ \\
\hline $\mathrm{Y} 13$ & 0.765 & 0.034 & $22.75^{*}$ & 0.244 & 0.013 & $18.65^{*}$ & 0.585 & 0.052 & $11.32^{*}$ \\
\hline Y14 & 0.762 & 0.034 & 22.4 & 0.241 & 0.011 & 22.94 & 0.581 & 0.051 & 11.32 \\
\hline Y15 & 0.752 & 0.030 & $24.85^{*}$ & 0.245 & 0.015 & $16.49^{*}$ & 0.565 & 0.045 & $12.44^{*}$ \\
\hline $\mathrm{Y} 16$ & 0.660 & 0.053 & $12.51^{*}$ & 0.215 & 0.014 & $15.25^{*}$ & 0.436 & 0.069 & $6.35^{*}$ \\
\hline Competitive Strategy (Y2) & \multicolumn{9}{|c|}{ AVE $=0.537$, Alpha $=0.876$} \\
\hline Y21 & 0.752 & 0.032 & $23.17^{*}$ & 0.181 & 0.010 & $18.02^{*}$ & 0.566 & 0.048 & $11.74^{*}$ \\
\hline Y22 & 0.680 & 0.049 & $13.77^{*}$ & 0.159 & 0.011 & 14.18 & 0.463 & 0.067 & $6.9^{*}$ \\
\hline Y23 & 0.675 & 0.053 & $12.64^{*}$ & 0.165 & 0.010 & $16.14^{*}$ & 0.456 & 0.071 & $6.47^{*}$ \\
\hline Y24 & 0.786 & 0.038 & $20.92^{*}$ & 0.175 & 0.010 & 18.12 & 0.618 & 0.058 & $10.59^{*}$ \\
\hline Y25 & 0.759 & 0.033 & $22.65^{*}$ & 0.168 & 0.008 & 21.56 & 0.575 & 0.051 & $11.33^{*}$ \\
\hline Y26 & 0.753 & 0.040 & $18.64^{*}$ & 0.174 & 0.008 & 20.95 & 0.567 & 0.060 & $9.42^{*}$ \\
\hline Y27 & 0.727 & 0.039 & $18.59^{*}$ & 0.170 & 0.009 & $19.16^{*}$ & 0.529 & 0.057 & 9.34 \\
\hline Y28 & 0.723 & 0.040 & $18.29^{*}$ & 0.172 & 0.007 & 25.62 & 0.522 & 0.057 & $9.15^{*}$ \\
\hline Kinerja (Y3) & \multicolumn{9}{|c|}{ AVE $=0.831$, Alpha $=0.792$} \\
\hline Y31 & 0.866 & 0.013 & $64.7^{*}$ & 0.402 & 0.011 & $36.67^{*}$ & 0.750 & 0.023 & $32.4^{*}$ \\
\hline Y32 & 0.955 & 0.005 & $190.36^{*}$ & 0.682 & 0.010 & $67.08^{*}$ & 0.913 & 0.010 & $95.23^{*}$ \\
\hline
\end{tabular}

Appendix 3 - Structural Model

\begin{tabular}{|l|l|l|l|}
\hline \multicolumn{1}{|c|}{ Path Coefficients } & Estimate & SE & CR \\
\hline Location $(\mathrm{X})->$ Competitive Environment (Y1) & 0.976 & 0.003 & 282.82 \\
\hline Location $(\mathrm{X})->$ Competitive Strategy (Y2) & 0.628 & 0.084 & 7.52 \\
\hline Location $(\mathrm{X})->$ Performance (Y3) & 0.148 & 0.107 & 1.39 \\
\hline Competitive Environment (Y1)->Competitive Strategy (Y2) & 0.357 & 0.084 & 4.26 \\
\hline Competitive Environment (Y1)->Perfromance(Y3) & 0.167 & 0.093 & 1.79 \\
\hline Competitive Strategy (Y2)->Perfromance (Y3) & 0.664 & 0.071 & 9.29 \\
\hline
\end{tabular}

$C R^{*}=$ significant at .05 level

Appendix 4 - Entire Model

\begin{tabular}{|l|l|}
\hline & Model Fit \\
\hline FIT & 0.590 \\
\hline AFIT & 0.584 \\
\hline
\end{tabular}

